\title{
薄膜のしわの解析モデルの検証について
}

\section{A study on verification of Mathematical Model of Wrinkle of Thin Membrane}

\section{○屋宮拓海（日大・院）}

Takumi Okumiya, Nihon University

$$
\text { 井上祥子（日大・院） }
$$

Shoko Inoue, Nihon University
宮崎康行（日大）

Yasuyuki Miyazaki, Nihon University

Key Words: <Thin-Membrane, Wrinkling>

\section{論文要旨}

This paper investigates Young's modulus and the stress-strain relation of a membrane with tensile test. A numerical study was carried out using the commercial finite element software ABAQUS to understand the effect of Young's modulus and the stress-strain relation on the deformation of a rectangular membrane under simple shear. The elastic region in the stress-strain curve is determined by comparing the tensilte test result and the nonlinear finite element analysis result, which is applied to the simple shear problem and the effect of the plastic deformation is evaluated.

\section{1.はじめに}

人工衛星・探査機の開発において, 高速通信や深宇宙探査 などに有用である大型アンテナやソーラーセイルなどの大 型宇宙構造物の研究・開発が盛んに行われている.このよう な大型宇宙構造物を実現するため，超軽量・高収納な展開構 造物として，薄膜構造物，インフレータブル構造物などの柔 軟構造物が注目されている. 1996 年の NASA インフレータ ブルアンテナ展開実験機 Spartan-207 (Fig.1)の打上げや, 2010 年の ISAS/JAXA 小型ソーラーセイル実証機 IKAROS (Fig.2) の打上げなど，実用化に向けて宇宙実証が進められている. 実証に向けて設計段階で展開構造物の挙動や特性をあらか じめ予測することが必要であるが, 柔軟構造物はその軽量さ, 柔軟さ故に地上実験では重力, 空気抵抗の影響を大きく受け てしまい,それらの影響が非常に少ない宇宙空間での展開挙 動, 展開後形状やその特性を模擬することは困難となる. そ こで、これらを数值計算により予測する事が必須である.

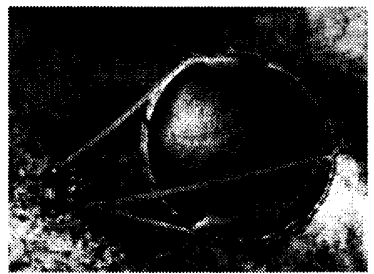

Fig.1 Spartan-207

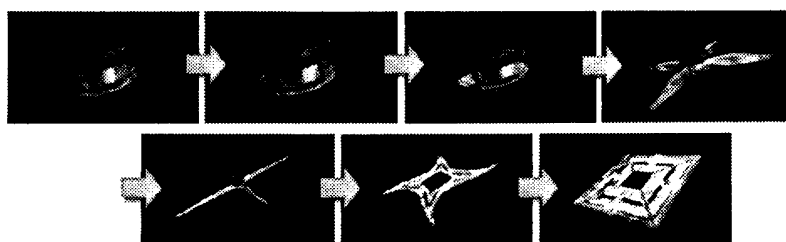

Fig.2 IKAROS

薄膜構造物に発生するしわを予測する数值計算手法には 大別して 2 つの有限要素法が用いられている. 1 目がシェ ル要素を用いたもので, しわの数や波長など詳細な形状を得 てしわの詳細な形状の検証を行う事に用いるが, 計算コスト が大きく実用的な大きさ・複雑さの構造物の解析や動解析に は現在までのところ, あまり用いられていない. 2 つ目は膜 要素を用いたもので, 曲げ応力を無視し平面応力場を仮定し た要素である.このモデルは計算コストが低いため, IKAROS
の展開シミュレーション旦をはじめ，実用的な大きさ・複雑 さの薄膜構造物の解析に用いられている. しかしこのモデル ではしわの 3 次元形状を得ることができない，著者らはこれ まで膜要素を用いた解析でしわの発生する領域・強さを表現 できる手法を提案してきた ${ }^{[3][4]}$. さらに膜面に強制変位を与 えてしわ形状を計測する実験を行い, 解析結果の妥当性評価 を試みてきた. 初期値しかし実験にて膜面にかかる荷重を計 測したところ, 数值計算結果よりも $40 \%$ 程度小さい值を示し ていることが分かった. 解析と実験で荷重値が一致しない原 因として以下の 2 つが考えられる。

(1) 実験にて膜面を治具に固定している部分の接着の問題 で，完全に膜が固定されておらず荷重の減少を招いて いる。

(2) 解析では膜面モデルに完全な弾性理論を用いているが, 実際には塑性変形を起こし解析よりも小さい荷重の値 をとっている.

本研究は(2)の可能性を検証する事を目的としたものであ る.この検証を行うにあたり, 膜材の引張試験を行い, 膜材 の性値を得た。そして，この得られた物性値が妥当であるか どうかを確かめるために, 構造解析に広く用いられている汎 用非線形有限要素解析プログラム ABAQUS を用い, 引張試 験と矩形膜のせん断実験のシミュレーションを行った. 引張 試験のシミュレーションでは, シミュレーションにより得ら れた応力-歪線図と, 実験で得られた応力-歪線図とを比較し 弾性限界值を調べた。 そして，せん断実験で与えたせん断量 が弾性域の範囲内であることを確認し，せん断実験のシミュ レーションが実験に近い結果になることを示し, 従来の膜面 モデルの解析に用いてきた物性値と実際に計測した膜材の 物性值との相違がシミュレーション結果にどの程度影響す るのか調バた。

\section{2. 引張試験}

2-1 実験概要

本試験の目的は，研究に用いているポリイミド膜の引張試 験を行い，ヤング率，弾性限界の値を得ることである。さら に，現在の解析モデルに用いている諸物性值が妥当であるか 検証する。

\section{2-2 実験装置及び手順}

試験のモデルには JIS_K7127 試験片タイプ 5 のダンベル 型, 試験片の全長 $115 \mathrm{~mm}$, 平衡部の長さ $33 \mathrm{~mm}$, 平衡部の幅 $6 \mathrm{~mm}$ ，標点閒距離 $25 \mathrm{~mm}$ ，厚み $12.5 \mu \mathrm{m}$ のポリイミド膜を使用 
した。引張試験機は INSTRON 5582 を使い引張速度 $50 \mathrm{~mm} / \mathrm{min}$ で試験を行った, データログ・マシン制御ソフト はBlue Hill3を使用した. 試料の平行部に 2 点の標点を打ち,

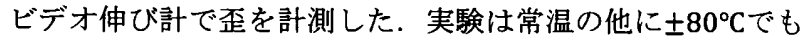
行った.これは宇宙空間での温度を模擬した物性值を得るこ とが今後の解析に関する様々な研究に対して有用であると 考えたためである、試験は各温度で 3 回ずつ, 合計 9 回行っ た.

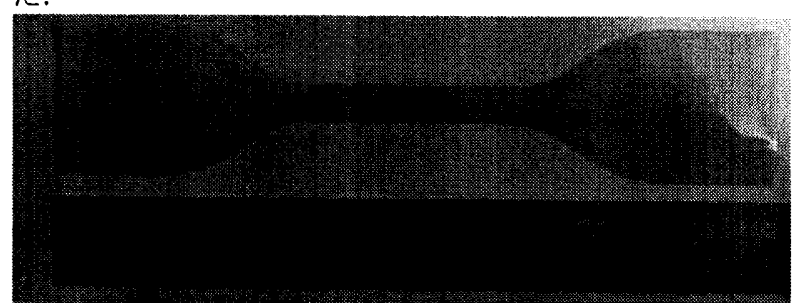

Fig.3 試験モデル（JIS_K7127 試験片タイプ 5)

\section{2-2 測定結果}

測定によって得られた SS 線図を Fig. 4 6に，破断後の試 験片の外観を Fig.7 に，引張試験中の試験片の外観を Fig.8 に示す。

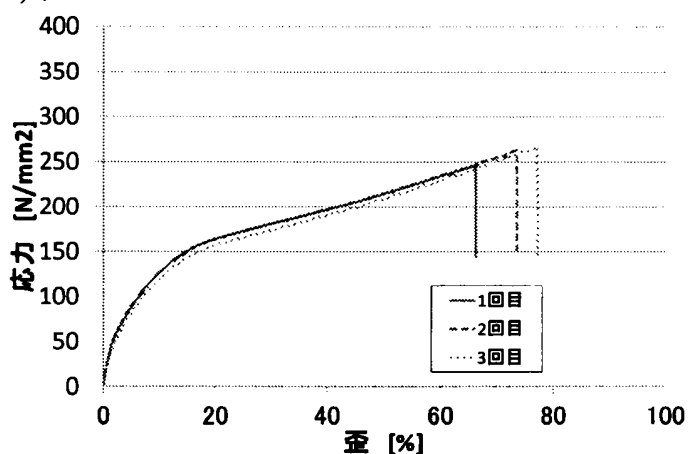

Fig.4 応力-歪線図(常温)

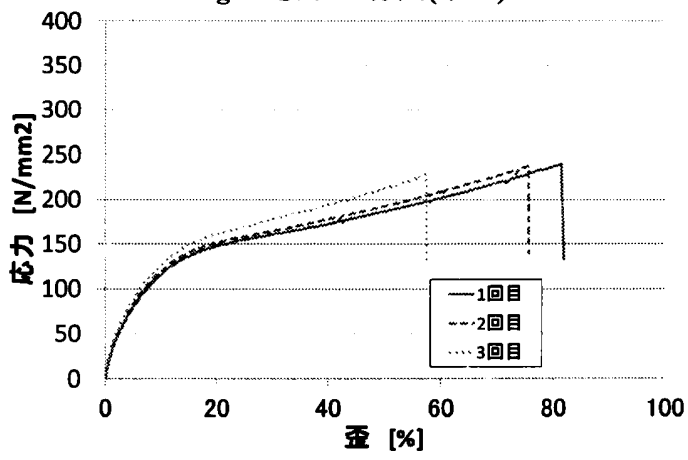

Fig.5 応力-歪線図 $\left(80^{\circ} \mathrm{C}\right)$

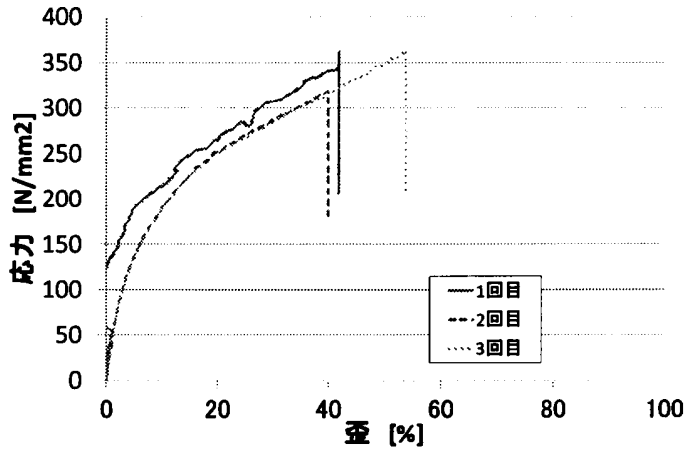

Fig.6 応力-歪線図 $\left(-80^{\circ} \mathrm{C}\right)$

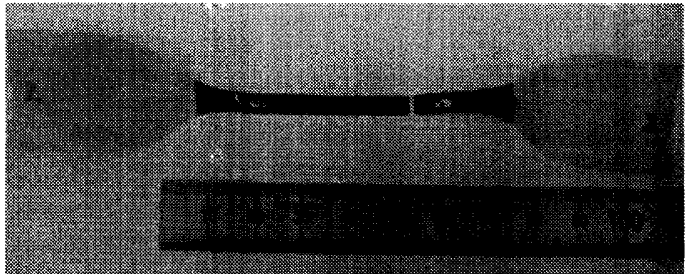

Fig.7 破断後の試酸片の外観

Fig4 6 より, 温度が高くなるほど柔らかく伸びやすい傾向 が見られ，一般に予想される通り，温度が低くなるほど硬く 伸びにくいという性質を確認した. また, Fig.3 と Fig.7を比 較するとポアソン効果が見られることが分かる. 破断時の幅 は平均して 3.8mm だったので，収縮率は 36\%だった。

次に, Table.1 に Blue Hill3 によって計算された各サンプル におけるヤング率を示す.

\begin{tabular}{|c|c|c|}
\hline 温度屌 & サンプル要 & ヤング率[Gpa] \\
\hline \multirow{3}{*}{80} & 1 & 3.15 \\
\hline & 2 & 3.38 \\
\hline & 3 & 3.65 \\
\hline \multirow{3}{*}{$\mathrm{F}: \mathrm{s}$} & 1 & 4.06 \\
\hline & 2 & 4.44 \\
\hline & ש 3 & 3.94 \\
\hline \multirow{3}{*}{-80} & 11 & 4.19 \\
\hline & 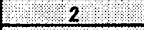 & 4.10 \\
\hline & 3 & 4.00 \\
\hline
\end{tabular}

2-3 節より，常温 2 回目の試験結果について, 詳細な検討を 述べる.

\section{2-3 京応力ー共歪線図}

引張試験によって得られた公称応力-歪線図に表わされ る物性を ABAQUS に反映させて解析を行うためには, 真応 力-塑性歪線図を求める必要がある。ここでは常温で最も平 均的な値だった 2 回目の試験結果から計算した真応力-真塑 性歪線図を Fig.8 に示す. ポアソン効果が見られたことから 体積一定で変形しようとする性質があると考えたため, 真応 力の導出には以下の式を用いた。

$$
\sigma_{\text {true }}=\sigma_{\text {normal }}\left(1+\varepsilon_{\text {normal }}\right)
$$

ここで $\sigma_{t r u e}$ は真応力, $\sigma_{\text {normal }}$ は公称応力, $\varepsilon_{\text {normal }}$ は公称歪 である. また，塑性歪を導出する．真全歪は，公称歪を以下 のように表すことで求めることが出来る.

$$
\varepsilon_{\text {normal }}=\frac{l-l_{0}}{l_{0}}=\frac{l}{l_{0}}-\frac{l_{0}}{l_{0}}=\frac{l}{l_{0}}-1
$$

式(2)の両辺に 1 を加え, 両辺の自然対数をとることにより, 真歪と公称歪の関係が得られる.

$$
\varepsilon^{t}=\ln \left(1+\varepsilon_{\text {normal }}\right)
$$

塑性歪は, 全歪の值から弾性歪を引くことで求められる. な お，弾性歪は，真応力をヤング率で割ることで求められる。

$$
\varepsilon^{p l}=\varepsilon^{t}-\varepsilon^{e l}=\varepsilon^{t}-\sigma_{\text {normal }} / E
$$

以上, 式(2) (4)より塑性歪が求められた. ここで， $\varepsilon^{p l}$ は真 塑性歪, $\varepsilon^{e l}$ は真弾性歪, $\varepsilon^{t}$ は真全歪, $E$ はヤング率である. 変形が大きくなるほど真応力の值は体積一定の条件だけで は正確な值から大きくずれていくと考えられるが，どれほど の変形までは式(1)のみの条件で再現できるのかを調べるた めに以下の手順で検証する.

1. 真応力-真塑性歪線図を用いた ABAQUS の計算モデルに て引張試験と同様の膜面形状と荷重条件で変形解析を行 う.

2. 1 の結果より, 実際の引張試験と同様の方法で公称応力 -歪線図を得てこれを実際の引張試験結果の公称応力-歪 
線図と比較する

3. これらの線図が一致する領域までは真応力の導出の方法, 即ち式(1)を用いた方法が適切であったと判断する.さら に, 真応力-真歪と公称応力-歪線図が一致する領域を弾性 域とする.

ただし，この弾性域が上記の手順で求める体積一定の条件 のみで再現できる領域内に入っている事を次の 3 章にて述べ る.

\section{2-4 数值解析}

ABAQUS での引張試験の解析方法を解説する. Fig.9に, 引張試験に使用した解析モデルを示す.

要素は四節点シェル要素 S4R5 を用い, 要素数 2234 節点数 2366 とした．要素分割の都合上，一部 S3 要素を用いた。

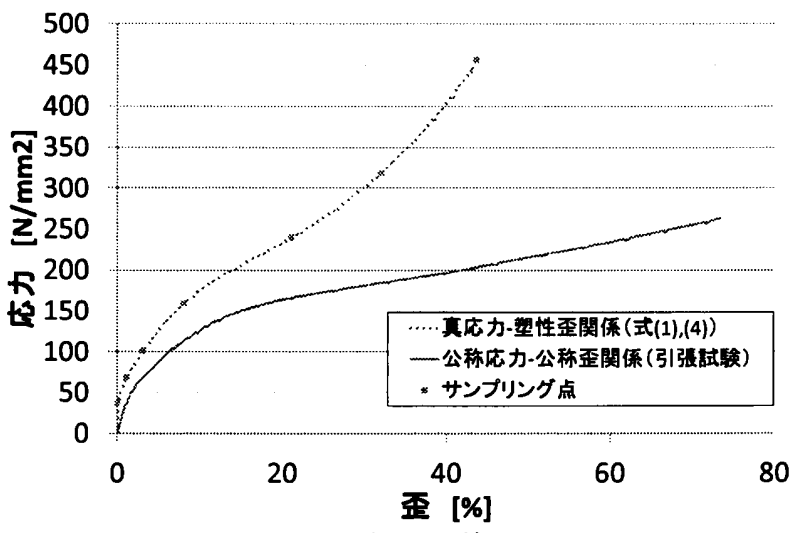

Fig.8 応力-歪線図

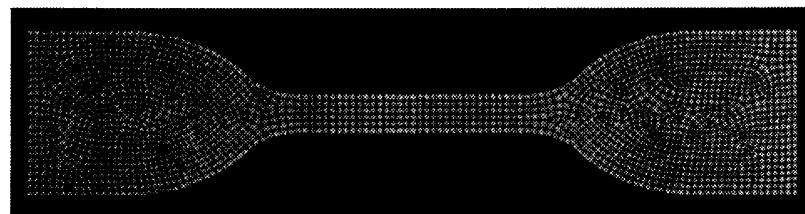

Fig.9 引張試験モデル

引張試験を模擬した解析を行い，得られた応力-歪関係を Fig.10 に示す. 2-3 節に示した手順にて体積一定の条件だけ で再現できる真応力-真歪の領域を検証したところ， Fig.10 より歪 $0.8 \%$ 末満の領域ではABAQUS の解析結果と実験で得 られた公称応力-歪線図が一致するので, 歪 $0.8 \%$ 未満の領域 までは式(1)が成り立つ弾性域と分かった。

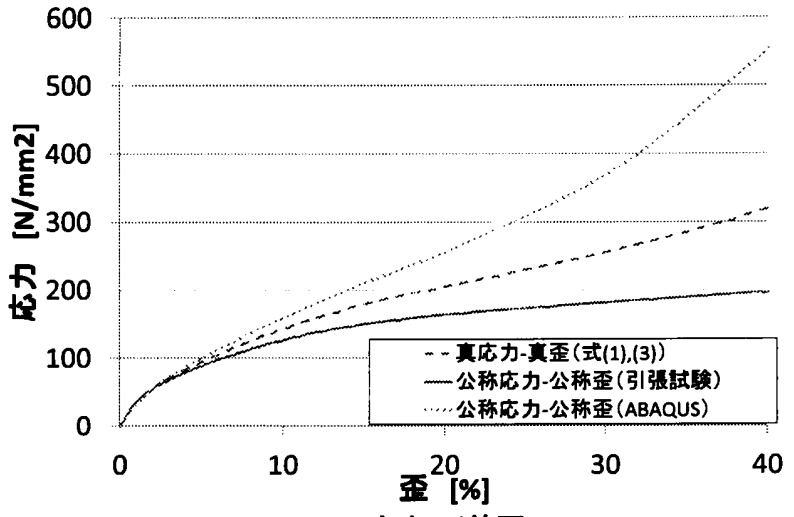

Fig.10 応力-丕線図

\section{3. 膜面のせん断実験}

3-1 実験モデル

得られた物性値が妥当なものなのか検証するため，膜面の せん断実験結果と得られた物性值を用いたシミュレーショ ン結果の検証を行った.

実験に用いた矩形せん断モデルの詳細及び，モデルパラメ 一タを示す．膜面は 2 つの治具により固定され，Fig.11の上 方に設置されているXY ステージにより片方の固定端を強制 変位させることで，膜面にしわを発生させている．膜面に発 生したしわは, CCD レーザ変位計により計測する. CCD レ 一ザ変位計は, $0.1[\mu \mathrm{m}]$ の分解能で計測可能である.

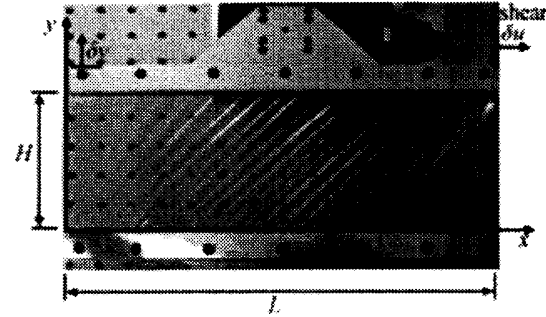

Fig.11 矩形せん断モデル

Table.2 矩形せん断モデルパラメータ

\begin{tabular}{|c|c|c|c|}
\hline 莫蝠 & $300[\mathrm{~mm}]$ & 变位 $($ (せん酐) $\delta u$ & $3[\mathrm{~mm}]$ \\
\hline 原高さ & $100[\mathrm{~mm}]$ & 赦位 (压樎) & $0.1[\mathrm{~mm}]$ \\
\hline 膜医 & $12.5[\mu \mathrm{m}]$ & $\begin{array}{lll}\text { X゚TYบ } & v\end{array}$ & 0.3 \\
\hline
\end{tabular}

\section{3-2 せん断量と弾性域}

せん断量が弾性域の中に入っているか調べる. Fig.12のよ うな矩形膜の角度 $\theta$ の線 $\mathrm{AB}$ が $\delta$ だけ，せん断変形し，変形 後には Fig.13の AB'になったとする.このとき，この線の 伸び歪は次の様になる。

$$
\begin{aligned}
\varepsilon & =\frac{\sqrt{H^{2}+(H / \tan \theta+\delta)^{2}}-(H / \sin \theta)}{H / \sin \theta} \\
& =\sqrt{1+\frac{2 \sin \theta \cos \theta}{H} \delta}-1 \\
& \approx \frac{\delta}{H} \sin \theta \cos \theta
\end{aligned}
$$

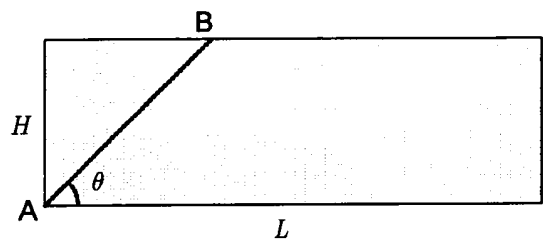

Fig.12 せん断変形前

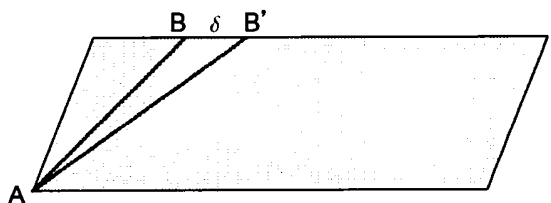

Fig.13 せん断変形後

式(5)において， $\theta$ と $H$ を定める事により伸び歪 $\varepsilon$ とせん断 変位量 $\delta$ の関係が得られる. 本研究に用いている膜面の形状 モデルについて，2-3 節で求められた弾性限界の歪の $0.8 \%$ の 時の $\delta$ は $1.6 \mathrm{~mm}$ となる. 従って $1.6 \mathrm{~mm}$ 末満のせん断変形は 弾性変形であると言える. 但し $\theta$ は $45^{\circ}$ としている. 


\section{3-3 数値解析}

弾性変形内の膜面のせん断変位の実験の解析を ABAQUS で行った. 要素は四節点シェル要素 S4R5 を用い, 要素数 7500 , 節点数 7701 とした. 解析は, 最初に一 $\delta \mathrm{v}$ 方向に0.1[mm]たる ませて，そこからー $\delta \mathrm{u}$ 方向に $1[\mathrm{~mm}]$ せん断した．重力を考慮 した。 ヤング率は, 引張試験で得られた 4.15[GPa]を使用し た.

\section{3-4 解析結果}

Fig.12 に ABAQUS でのしわの解析結果を示す.

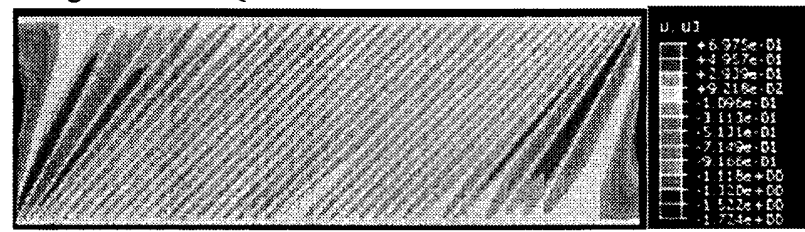

Fig.13 ABAQUS の解析結果

青色の部分が $\mathrm{Z}$ 軸の負の方向の変位であり, 赤色の部分が $\mathrm{Z}$ 軸に正の方向の変位である. 左上と右下の部分がたるんで おり,一番自由端に近い所にできるしわの変位が大きいこと がわかる

Fig.14 に実験結果と ABAQUS による解析結果の中央断面で のしわ形状の比較したものを示す.

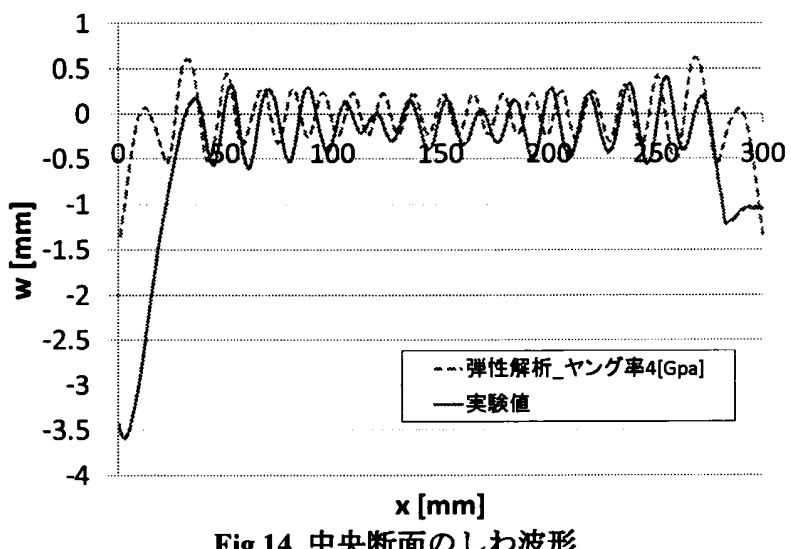

Fig.14 を定性的にみると，自由端に近づくにつれ，しわの高 さが大きくなく傾向が解析できている.

Fig.13 と 14 より, 解析におけるしわの発生状況が, 実験に おけるしわの発生状況の傾向に, よく一致していることがわ かる.

次に，物性值の違いが，膜面のせん断実験に与える影響に ついて調べるために，従来用いてきたヤング率と実験から得 られたヤング率を用いた弾性解析と，実験から得られた塑性 を考慮した弾塑性解析を行った。 そして，3-2 節で確かめた せん断変形の領域が弾性域なのかを確かめた。

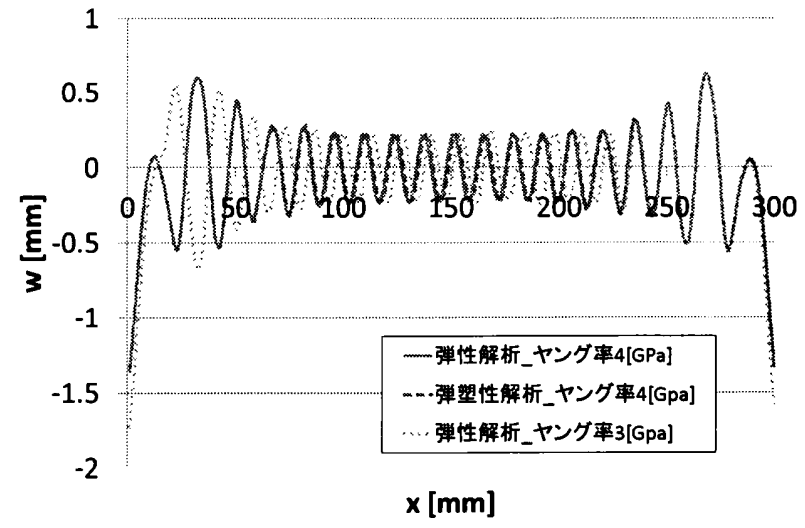

Fig.15 中央断面のしわ波形

Fig.15より弾性解析と弾塑性解析では，ほぼ一致したしわ の断面形状となっていることから，せん断量 $1[\mathrm{~mm}]$ は塑性変 形の入っていない領域である事が確認された. 1 章に示した 本研究の目的に対して, 実験にて得られた荷重が解析より得 られた荷重より小さい值をとる原因として塑性変形の可能 性を除去する事ができるという結論が得られた。

\section{4. おわりに}

本研究では，膜材の引張試験結果をそれに対応した非線形 有限要素解析結果から公称応力-公称歪関係における弾性領 域を判定する方法を示した. そして，これを膜面のせん断実 験に適用することで, 塑性変形の影響を評価した.これまで, 実験と FEM とで膜面にかかる荷重が大きく異なる原因の 1 つとして塑性変形の影響を考えていたが, 今回の解析の結果, その影響はないとの結論を得た．今後は，時間が経つと応力 が减少する現象も含め, 固定方法の影響について調心゙, 膜面 の固定方法の改善を行っていきたい.

なお, 本研究の一部は文科省科研費・基盤研究(B)22360357 の支援によるものである.

[1] Miyazaki, Y., et. al., "Conserving Finite Element Dynamics of Gossamer Structure and Its Application to Spinning Solar Sail "IKAROS"', 52nd AIAA/ASME/ASCE/AHS/ASC Structures, Structural Dynamics, and Materials Conference, AIAA-2011-2181, 2011,1-17, Denver, CO.

[2]Iwasa, T., Natori, M.C., and Higuchi, K., "Evaluation of Tension Field Theory for Wrinkling Analysis With Respect to the Post-Buckling Study", Journal of Applied Mechanics, Vol.71, 2004, pp.532-540.

[3]Miyazaki, Y., "Wrinkle/slack model and finite element dynamics of membrane", International Journal for Numerical Methods in Engineering, Vol.66, No.7, May 2006, pp.1179-1209. [4]Miyazaki, Y. and Arita, K., "Simplified Model of Membrane for Wrinkle Analysis of Gossamer Structure", 49th AIAA/ASME/ASCE/AHS/ASC Structures, Structural Dynamics and Materials Conference, AIAA2008-2134, 7-10 April 2008. Schaumburg, IL. 